\title{
USE OF THE GEOTHERMAL GRADIENT VARIATIONS IN ZONING OF POST- MIOCENE SEQUENCE IN THE NILE DELTA, EGYPT
}

\author{
Ahmad Sobhy Helaly \\ Department of Geophysics, Faculty of Science, Ain Sham University, Cairo, Egypt \\ E-mail: Ahmad.Helaly@sci.asu.edu.eg
}

\begin{abstract}
Among the most important thermal parameters of the rocks and their composing minerals is the Geothermal Gradient. Geothermal gradient plays an important role in expressing the subsurface thermal conditions in any area. After carrying out the required corrections for the thermal data in hand, it was used for estimating and illustrating the Geothermal Gradient variations with depth. Using such results, an attempt was carried out to use such variations to identify the subsurface lithologic compositional variations in the study area based on the thermal characteristics of the different subsurface lithologies.Four main subsurface units were identified and mapped within the Nile Delta.
\end{abstract}

Keywords: Bottom-hole temperature, Harrison correction, Forster correction, AAPG correction, Geothermal Gradient, Miocene.

\section{INTRODUCTION}

The Nile Delta Basin had become the most important energy source in Egypt in the last few decades in the early 1960s with the recent gas discoveries.Although the Nile Delta has been predominantly considered as important gas province, the analyses of potential source rocks in the Miocene have identified oil was found in a number of wells, which may indicate the possibility presence of commercial oil occurrences (Shehata, 2008). The study area is located between latitudes $30^{\circ} 00^{\prime} 00^{\prime \prime} \mathrm{N} \mathrm{\&} 31^{\circ} 45^{\prime} 00^{\prime \prime} \mathrm{N}$ and longitudes $30^{\circ} 00^{\prime} 00^{\prime \prime} \mathrm{E} \& 32^{\circ} 00^{\prime} 00^{\prime \prime} \mathrm{E}$ (Fig. 1). The main objective of this paper is to evaluate the potentiality of using the geothermal gradient in identifying the subsurface lithologies and classifying the subsurface sequence based on their geothermal characteristics, within the Nile Delta region.

\section{GENERAL GEOLOGIC SETTING OF THE NILE DELTA}

The Nile Delta lies on the slightly deformed outer northeastern margin of the African plate. It includes the onshore and offshore parts. The onshore part is represented by a wide and deep basin, which is structurally and stratigraphically divided into eastern, central and western sub-basins. These basins are characterized by the presence of thick Plio-Pleistocene sediments associated with extensive NW trending shallow listric faults (Abdel Aal, et al. 1994).

The Miocene sediments are characterized the presence of Abu Madi channel which is considered to be the main gas-producing horizon in the Nile Delta. Abu El Ella (1990) stated that the Nile Delta was structurally controlled by different fault patterns, which were tectonically extended from Late Paleozoic to recent. These fault patterns had different trends as E-W trend called the hinge zone, NW-SE trend called El Temsah Trend, NE-SW trend called Rosetta trend and N-S trend called Baltim trend. These previous faults effect on the Nile Delta area controlling the reservoir trapping with minor other faults. Many authors had dealt with studying the structural setting of the Nile Delta area as (Rizzini, et al., 1976; Kora, 1980; Deibis, et al. 1986; Abd El Aal, 1992; Arisi Rota, 1994; Sarhan and Hemdan, 1994; Zaghloul, et al., 2001a; Zaghloul, et al., 2001b; Zaghloul, et al., 2001c; Elbosraty, M., 2005; and Khaled, 2014) and others. The sedimentary rocks penetrated in the Nile Delta basin consist of thick clastics sediments representing Miocene-Holocene time interval (Sarhanand Hemdan, 1994). These rocks were described by (Abdel Aal, et al., 1994, Zaghloul, et al, 2001a and Zaghloul, et al, 2001b). 
Helaly, A. S.
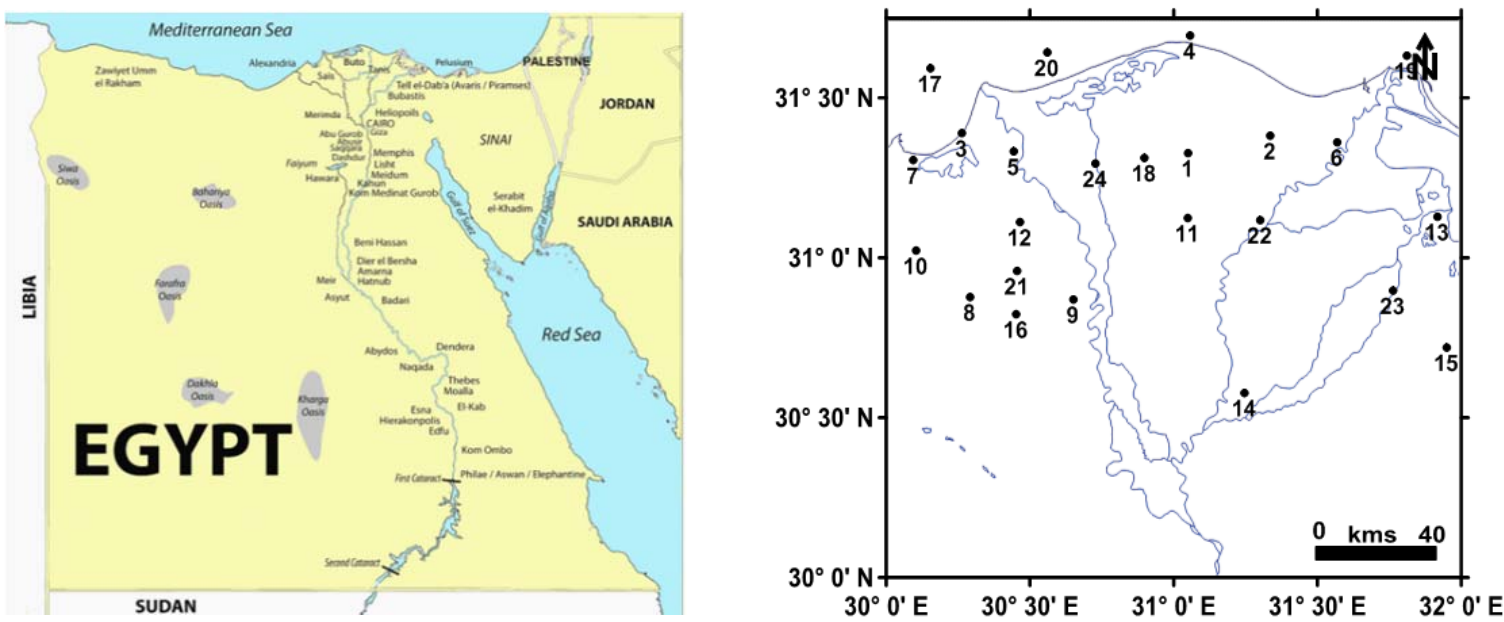

Fig.1: Location map with the penetrated wells used in Nile Delta study area.

The current study is concerned mainly with the relatively shallow recent succession of the Neogene and Quaternary rocks (Fig. 2). Most of the drilled wells did not reachthe Lower Miocene because the penetrated Middle Miocene rocks (fine clastics) were thought to be very thick (about $3000 \mathrm{~m}$ ) (Said, 1962). Late/Upper Miocene rocks are missing in all Tertiary sections except in some localities in Eastern Delta and Sinai (Elbosraty, 2005). A series of en-echelon faults which developed subparallel to the Mediterranean coast and affected the Nile Delta's pre-Oligocene rocks (Shehata, 2008; Abu El Ella, 1990; Mosconi, et al., 1996 and Hemdan, et al., 2002).

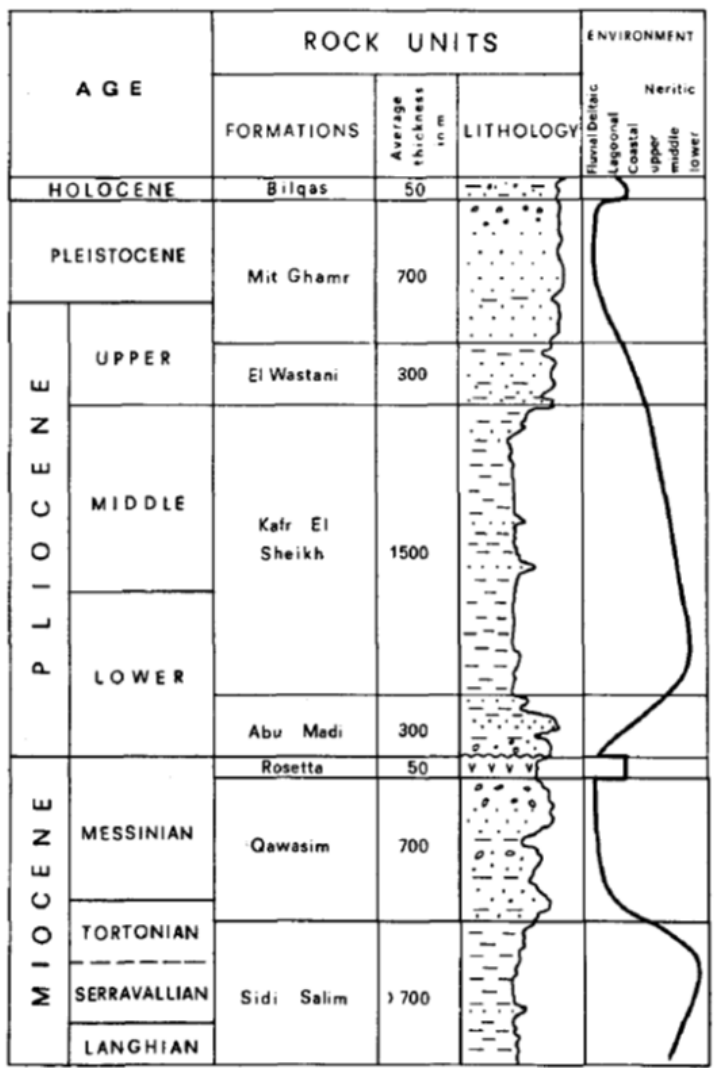

Fig. 2: Composite Neogene-Quaternary stratigraphic column including average thickness and environment of the examined formation (Abu El Ella, 1990).

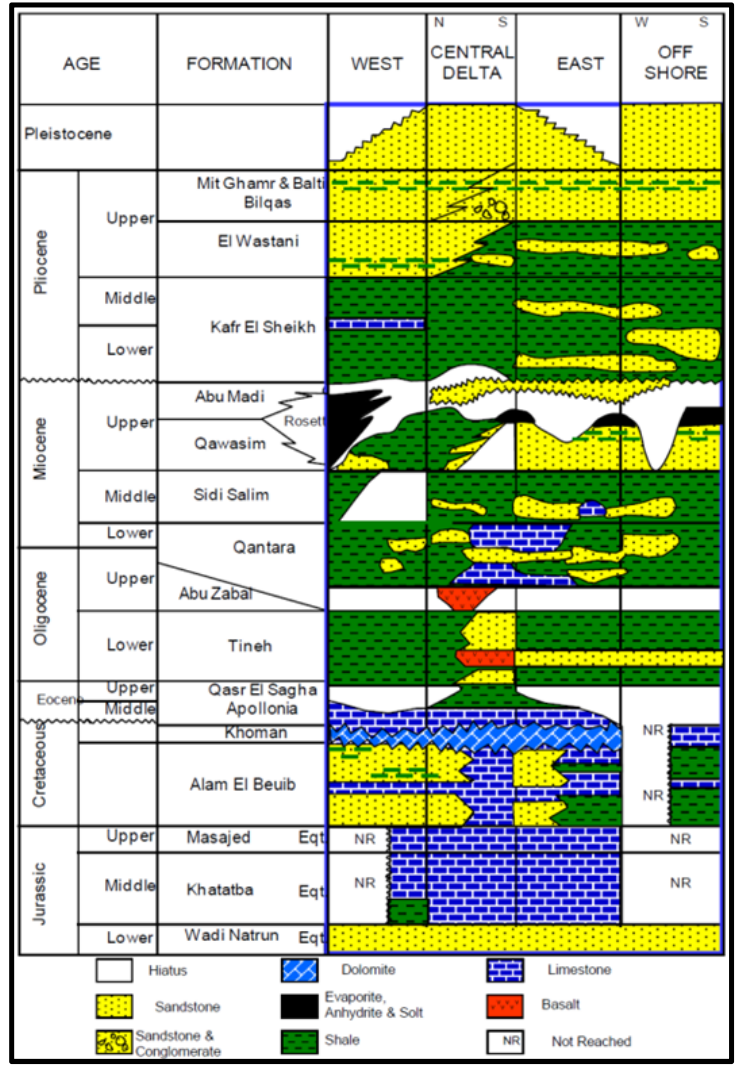

Fig. 3: Generalized lithostratigraphic section of the Nile Delta (Egyptian General Petroleum Corporation, 1994). 
Use of the geothermal gradient variations in zoning of Post- Miocene Sequence

\section{GENERAL STRATIGRAPHIC FRAMEWORK}

Stratigraphically, the essential clastic sediments within the Nile Delta consist of three distinct sedimentary cycles: a Miocene cycle whose base is unknown; a Plio-Quaternary cycle and a Holocene cycle (Zaghloul, 2001a) as shown in Fig. 3.

\section{Miocene Cycle}

Drilling of wells in the central part of the Nile Delta basin generally stopped in the middle of a clayey formation, the SidiSalim Formation (Rizzini, et al. 1976).

\section{Moghra Formation (Early Miocene)}

Moghra Formation consists of marine to fluvio-marine deposits (shale and sandstone) of presumed deltaic origin, although it is associated with marine carbonate intervals. This formation is unconformably overlain by Sidi Salem Formation.

\section{SidiSalim Formation (Middle Miocene)}

This formation is composed mainly of clayey mudstone composition with a few intervals of dolomitic marls and rare interbeddings of sandstones and siltstones. This formation corresponds to a lower neritic slope environment.

Qawasim Formation: is composed of a fairly irregular succession of thick layers of sands, sandstones and conglomerates interbedded with clay layers.

Rosetta Anhydrites Formation: is only a few tens of meters thick, composed of thick layers of anhydrite interbedded with thin layers of clays.

\section{Pliocenic-Pleistocenic and Holocenic Cycles}

The Lower marine Pliocene lies, sometimes with an associated angular unconformity, on the Qawasim Formation. The sedimentation then proceeds with the clearly marine clays of the Kafr E1 Sheikh Formation. The basin tends, then, to fill up gradually with the deposition of littoral and fluvial sands of the E1 Wastani and MitGhamr Formations. The appearance of the Holocene transgression is marked by a few tens of meters of sediments of the Bilqas Formation.

Abu Madi Formation: is composed of large, thick layers of interbedded sandstones and mudstones, rarely conglomeratic, interbedded with clay layers which become thicker and more frequent in the upper part of the formation.

\section{Kafr El Sheikh Formation (Early-middle Pliocene)}

This formation consists of soft clay in the form of mudstone sequence with thin limestone and sandstone interbeds (Abd El Aal, et al., 1992). Zaghloul, et al. (2001a) suggested that, the Kafr El Sheikh Formation is accumulated as neritic mudstones on the present onshore delta- and in a basinal setting offshore. This formation is conformably overlain by El Wastani Formation.

El Wastani Formation: consists of thick sand beds interbedded with thin clay levels which become thinner toward the top of the formation.

MitGhamr Formation (Late pliocene): consists of thick layers of sand and pebbles which only in the lower part of the formation show clay interbeddings of limited thickness. It conformably underlies the Bilqas Formation.

Bilqas Formation (Holocene): consists of sand interbedded with clay.

Summary of the described formations is given in Table (1). 
Helaly, A. S.

Table 1: Informative Summary of the described formations (Rizzini, et al., 1976)

\begin{tabular}{|c|c|c|c|c|c|c|}
\hline Age & $\mathrm{Fm}$ & $\begin{array}{c}\text { Type Sectionin } \\
\text { Well...... }\end{array}$ & Coordinates & $\begin{array}{l}\text { Depth Range } \\
(\mathrm{m})\end{array}$ & $\begin{array}{l}\text { Thickness } \\
(\mathrm{m})\end{array}$ & Main Lithology \\
\hline Holocene & Bilqas & Bilqas\#1 & $\begin{array}{l}X=645960 \mathrm{E} \\
Y=940560 \mathrm{~N}\end{array}$ & 0 to 25 & 25 & $\begin{array}{l}\text { Sand } \\
\text { interbedded with } \\
\text { clay }\end{array}$ \\
\hline $\begin{array}{l}\text { U. Pliocene } \\
\text { - leistocene }\end{array}$ & Mit Ghamr & Mit Ghamr\#1 & $\begin{array}{l}30^{\circ} 41^{\prime} 44^{\prime \prime N} \\
30^{\circ} 16^{\prime} 26^{\prime \prime} \mathrm{E}\end{array}$ & 20 to 483 & 463 & $\begin{array}{l}\text { Sand and } \\
\text { pebbles }\end{array}$ \\
\hline U. Pliocene & El Wastani & El Wastani\#1 & $\begin{array}{l}31^{\circ} 24^{\prime} 8.750^{\prime \prime N} \\
31^{\circ} 35^{\prime} 46.694^{\prime \prime} \mathrm{E}\end{array}$ & 1009 to 1132 & 123 & $\begin{array}{l}\text { Quartzose } \\
\text { sandstone } \\
\text { interbedded with } \\
\text { clay }\end{array}$ \\
\hline $\begin{array}{l}\text { L.-M. } \\
\text { Pliocene }\end{array}$ & $\begin{array}{l}\text { Kafr El } \\
\text { Sheikh }\end{array}$ & Kafr E1 Sheikh\#1 & $\begin{array}{l}31^{\circ} 10^{\prime} 23^{\prime \prime N} \\
31^{\circ} 4^{\prime} 55^{\prime \prime} \mathrm{E}\end{array}$ & 1277 to 2735 & 1458 & $\begin{array}{l}\text { Clay (mudstone) } \\
\text { interbedded with } \\
\text { sands }\end{array}$ \\
\hline L. Pliocene & Abu Madi & Abu Madi\#1 & $\begin{array}{l}31^{\circ} 26^{\prime} 17.396 " \mathrm{~N} \\
31^{\circ} 21^{\prime} 41.726^{\prime \prime} \mathrm{E}\end{array}$ & 3007 to 3329 & 322 & $\begin{array}{l}\text { Cross-bedded } \\
\text { Sand } \\
\text { interbedded with } \\
\text { clay }\end{array}$ \\
\hline M. Miocene & Rosetta & Rosetta & $\begin{array}{l}31^{\circ} 37^{\prime 2} 2.65 " \mathrm{~N} \\
30^{\circ} 31 ' 34.18 " \mathrm{E}\end{array}$ & 2678 to 2718 & 40 & Anhydrite \\
\hline M. Miocene & Qawasim & Qawasim\#1 & $\begin{array}{l}31^{\circ} 20^{\prime} 07^{\prime \prime N} \\
30^{\circ} 50^{\prime} 55^{\prime \prime} \mathrm{E}\end{array}$ & 2800 to 3733 & 933 & $\begin{array}{l}\text { Sands, } \\
\text { sandstones }\end{array}$ \\
\hline L. Miocene & Sidi Salim & Sidi Salim\#1 & $\begin{array}{l}31^{\circ} 19^{\prime} 10.5 " \mathrm{~N} \\
30^{\circ} 43^{\prime} 16.6 " \mathrm{E}\end{array}$ & 3592 to 4038 & 446 & Clay \\
\hline
\end{tabular}

\section{AVAILABLE DATA AND METHODOLOGY}

The temperature data from twenty four (24) wells (Fig. 1) were used in the current study in the form of three data sets,the surface temperature, the bottom-hole temperature and some temperature values measured at different depths through each penetrated well. The available temperature data set from each well was digitized at 50 meters depth intervals to get as much detailed new data sets as possible for subsequent analysis. Table (2) manipulates the total depth and bottom-hole temperatures in the studied wells.

Table 2: Illustrates the available well information used in the current study

\begin{tabular}{|c|c|c|c|c|c|c|c|}
\hline No. & Well Name & $\begin{array}{l}\text { Bottom-hole } \\
\text { Depth (m) }\end{array}$ & $\begin{array}{l}\text { Bottom-hole } \\
\text { Temperature }\left({ }^{\mathrm{O}} \mathrm{C}\right)\end{array}$ & No. & Well Name & $\begin{array}{l}\text { Bottom-hole } \\
\text { Depth } \\
\text { (m) }\end{array}$ & $\begin{array}{c}\text { Bottom-hole } \\
\text { Temperature } \\
\left(^{\mathbf{O}} \mathbf{C}\right)\end{array}$ \\
\hline 1 & Abadiya-1 & 3620 & 104 & 13 & Matariya-1 & 4150 & 122 \\
\hline 2 & Abu Madi-2 & 4040 & 120 & 14 & $\begin{array}{l}\text { Mit Ghamr- } \\
1\end{array}$ & 2180 & 83 \\
\hline 3 & Abu Qir & 2846 & 85 & 15 & Monaga-1 & 3480 & 100 \\
\hline 4 & Baltim-1 & 3660 & 108 & 16 & N.Dilingat-1 & 2118 & 71 \\
\hline 5 & Buseili-1 & 2420 & 72 & 17 & NAF-1 & 3882 & 93 \\
\hline 6 & El Wastani-1 & 3450 & 96 & 18 & Qawasim-1 & 3710 & 103 \\
\hline 7 & El-Tabia & 2393 & 71 & 19 & Ras El-Bar-1 & 4444 & 115 \\
\hline 8 & Hosh Isa & 2084 & 73 & 20 & Rosetta-2 & 3240 & 96 \\
\hline 9 & Itay El-Baroud-1 & 2351 & 74 & 21 & $\begin{array}{l}\text { S. } \\
\text { Damanhour- } \\
1\end{array}$ & 2617 & 79 \\
\hline 10 & Kafr El-Dawar & 2655 & 80 & 22 & $\begin{array}{l}\text { S.W. Bilqas- } \\
1\end{array}$ & 4380 & 120 \\
\hline 11 & Kafr El-Sheikh-1 & 4080 & 105 & 23 & $\begin{array}{l}\text { San El- } \\
\text { Hagar-1 }\end{array}$ & 3720 & 115 \\
\hline 12 & Mahmoudiya-1 & 2404 & 69 & 24 & Sidi Salim-1 & 3850 & 106 \\
\hline
\end{tabular}


Use of the geothermal gradient variations in zoning of Post- Miocene Sequence

\section{Temperature Corrections}

The available temperature data from each well were analyzed and corrected through different temperature correction procedures. The use of such different correction schemes from different geographic areas makes the application of these corrections to other basins unfitting since different basins usually have different lithologies and thermal histories (Crowell, et al., 2011). But usually applying such correction schemes can be used in different areas for giving an approximate corrected temperature values suiting the studied areas; in general. Six correction schemes have been used in the current study to reach the most appropriate temperature values for their analysis:

1-The Harrison Correction, created by Harrison, et al., (1983) was determined using equilibrium and disequilibrium datafrom the Anadarko and Arkoma basins in Oklahoma. The Harrison Correction equation as defined by the Southern Methodist UniversityGeothermal Laboratory (Blackwell, 2004 and Blackwell, 2010) is:

$$
\Delta T\left({ }^{\circ} \mathrm{C}\right)=-16.512+0.0183 \times \mathrm{Z}-0.00000234 \times \mathrm{Z}^{2}
$$

Where $\mathrm{Z}$ is depth in meters.

2- The FörsterCorrection was created by analyzing bottom-hole temperature data in southeastern Kansas for the samereason: unreliable BHT records due to mud circulation (Kehle, 1973).Two versions of the Förster correction exist:

a) the original Förster correction equation (Kehle, 1973), which is:

$$
\Delta T\left({ }^{\circ} \mathrm{C}\right)=0.012 \times \mathrm{Z}-3.68
$$

Where $\mathrm{Z}$ is depth in meters. And

b) the equation that was modified by the SMU Geothermal Laboratory (Blackwell, 2004):

$$
\Delta T\left({ }^{\circ} \mathrm{C}\right)=0.017 \times \mathrm{Z}-6.58
$$

Where $\mathrm{Z}$ is depth in meters.

3- Forster/Merriam/Davis Correction(Förster,1996)

$$
\Delta T\left({ }^{\circ} \mathrm{C}\right)=0.0127 \times \mathrm{Z}-7.64
$$

Where $\mathrm{Z}$ is depth in meters.

4-AAPG Correction (Kehle, 1972, Forster, and Merriam, 1995)

$$
\Delta \boldsymbol{T}\left({ }^{\circ} \mathrm{C}\right)=1.878 \times 10^{-3} \times \mathbf{Z}+8.476 \times 10^{-7} \times \mathbf{Z}^{2}-5.091 \times 10^{-11} \times \mathbf{Z}^{3}-1.681 \times 10^{-14} \times \mathbf{Z}^{4}
$$

5- Andrews-Speed,et al., (1984)

Speed, et al., (1984) used to apply the correction through the following equation:

$$
T_{\text {Corrected }}=T_{S}+f \cdot\left(T_{m}-T_{S}\right)
$$

where $\mathbf{T}_{\mathbf{S}}$ is the surface temperature, $\mathbf{T}_{\mathbf{m}}$ is the measured temperature (to be corrected), and " $f$ " is a correction factor $(\boldsymbol{f}=1.15)$.

For all the correction procedures, the temperature correction factor $(\boldsymbol{\Delta T})$ is then added to the existing measurement to get the corrected temperature, except the last approach (Andrews-Speed et al) which computes the corrected temperature right away.

The available digitized uncorrected bottom-hole temperatures were then corrected using the mentionedsix procedures resulting in the creation of six new datasets. These six new datasets were then plotted in an Excel spreadsheet and fitted with a linear best fit trendline. The equations of the trendlines were recorded to obtain the area between the curves. The area between curves is interpreted to be a method by which to quantify the most accurate correction method (Fig. 4). The integration yieldingthe 
Helaly, A. S.

smallest area between the uncorrected and corrected curves is considered as the best of the existing corrections as defined by (Allis, et al., 2015).

Fig.4: Graphical representation of integration.

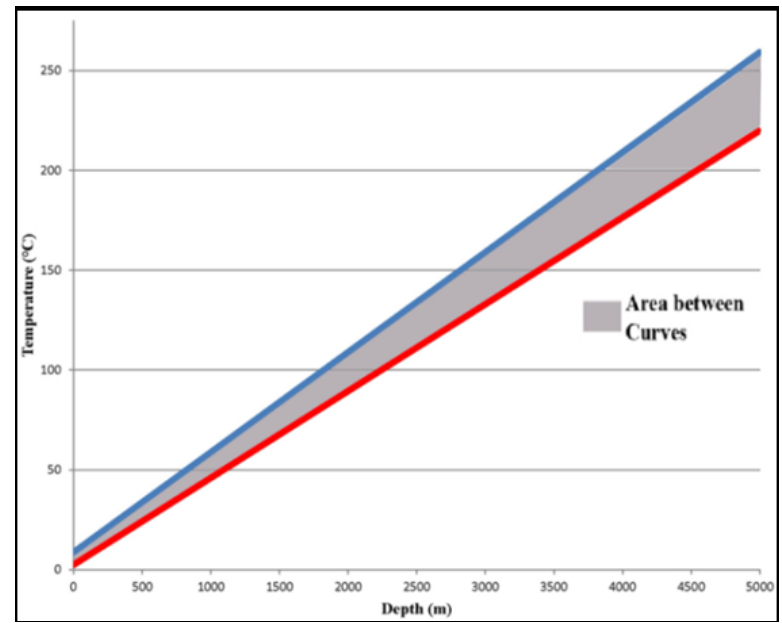

The procedures carried out for all uncorrected data, produced voluminous results from calculations which are inappropriate to be illustrated and tabulated in this text. Therefore, an example of the applied procedures will be presented here for just one well (as an example, e.g. Well\#1, Abadiya-1). Calculation results are illustrated in Fig. 5, while Fig. 6 shows the uncorrected and corrected temperature data for the same well. The marked graphed corrected temperature results from all analyzed wells have been chosen for the subsequent paper work, as shown in the following sections.

\section{Surface Distribution of the General Geothermal Gradient}

The general geothermal gradient has been calculated in all the studied wells for the available depth range in each well using the following equation:

$$
\text { (Geothermal Gradient) GG }=\frac{n \sum x \cdot y-\sum x \sum y}{n \sum x^{2}-\left(\sum x\right)^{2}}
$$

Where; $\boldsymbol{\rightarrow} \boldsymbol{y}=$ depth in meters, $\boldsymbol{x}=$ temperature in Celsius degrees, $\boldsymbol{n}$ is the number of data.

The resulted general geothermal gradient values are tabulated in Table (3) and mapped in Fig. 7 to illustrate its surface distribution within the study area. The general geothermal gradient values range from 3.35 to $4.78{ }^{\circ} \mathrm{C} / 100 \mathrm{~m}$. The highest geothermal gradient values were recognized in four spots within the study area, at well\# 6 (close to the Damietta branch to the East), at wells \# 5, 12, and, 24 (along the Rosetta branch to the West). Also, high values are found near the southeastern (well\#15) and northwestern (well\#17) corners of the Nile Delta.

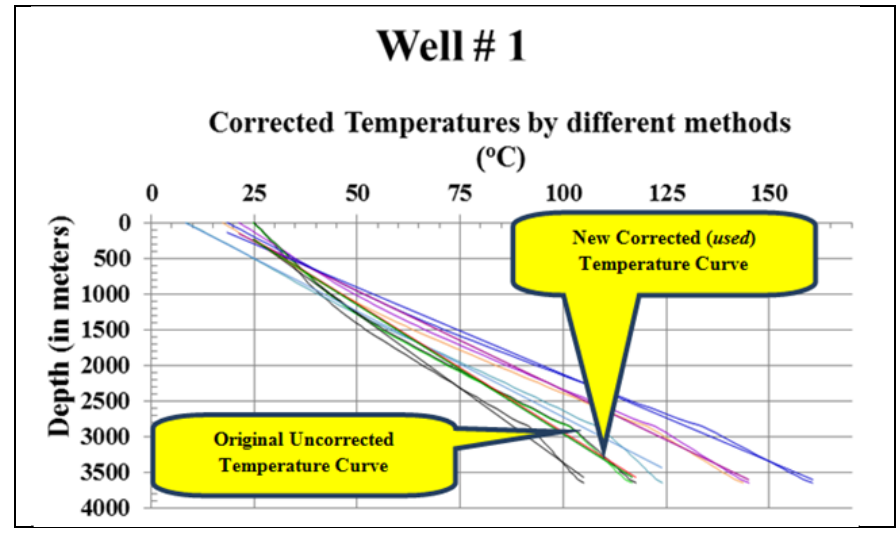

Fig. 5: Plot showing the Uncorrected and

Corrected Temperature Curves versus depth. 
Use of the geothermal gradient variations in zoning of Post- Miocene Sequence

Fig. 6: Plot showing the Uncorrected and the chosen Corrected Temperature curves versus depth

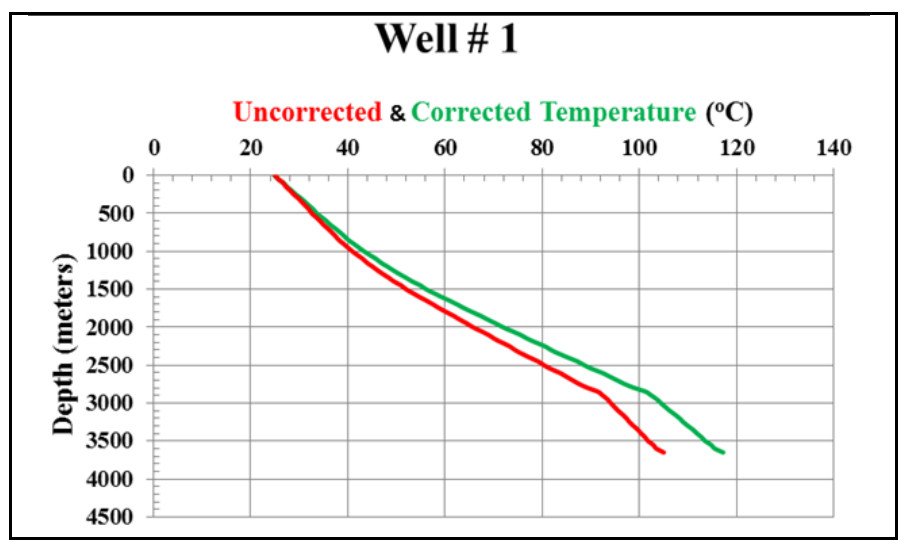

Table 3: Values of General geothermal gradient.

\begin{tabular}{|c|l|c|c|l|c|}
\hline No. & \multicolumn{1}{|c|}{ Well Name } & $\begin{array}{c}\text { Geothermal Gradient } \\
\left({ }^{\circ} \mathrm{C} / 100 \mathrm{~m}\right)\end{array}$ & No. & Well Name & $\begin{array}{c}\text { Geothermal Gradient } \\
\left({ }^{\circ} \mathrm{C} / 100 \mathrm{~m}\right)\end{array}$ \\
\hline 1 & Abadiya-1 & 3.62 & 13 & Matariya-1 & 4.34 \\
\hline 2 & Abu Madi-2 & 3.35 & 14 & Mit Ghamr-1 & 3.48 \\
\hline 3 & Abu Qir & 3.35 & 15 & Monaga-1 & 4.64 \\
\hline 4 & Baltim-1 & 4.30 & 16 & N.Dilingat-1 & 3.90 \\
\hline 5 & Buseili-1 & 4.54 & 17 & NAF-1 & 4.69 \\
\hline 6 & El Wastani-1 & 4.53 & 18 & Qawasim-1 & 3.99 \\
\hline 7 & El-Tabia & 4.13 & 19 & Ras El-Bar-1 & 4.08 \\
\hline 8 & Hosh Isa & 3.73 & 20 & Rosetta-2 & 3.95 \\
\hline 9 & Itay El-Baroud-1 & 4.21 & 21 & S. Damanhour-1 & 3.84 \\
\hline 10 & Kafr El-Dawar & 4.02 & 22 & S.W. Bilqas-1 & 3.95 \\
\hline 11 & Kafr El-Sheikh-1 & 4.18 & 23 & San El-Hagar-1 & 3.76 \\
\hline 12 & Mahmoudiya-1 & 4.45 & 24 & Sidi Salim-1 & 4.78 \\
\hline
\end{tabular}

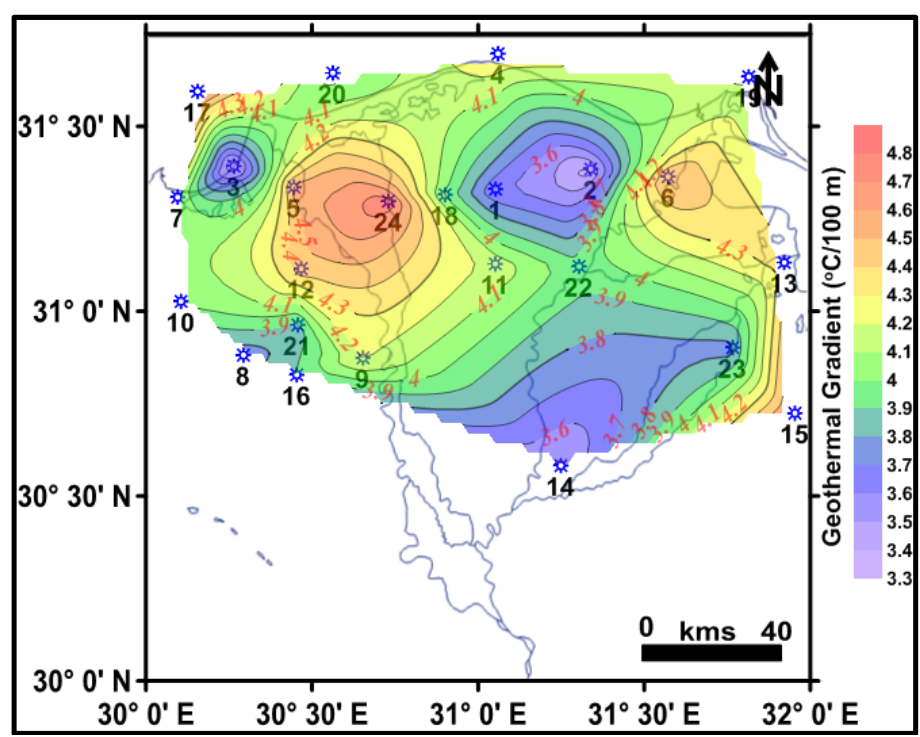

Fig. 7: General geothermal gradient. (C.I. $=0.1^{\circ} \mathrm{C} / 100$ meters)

The regional geothermal gradient within the study area is expressed in Figs. 8 and 9. Where; Fig. 8 was obtained through carrying out the $1^{\text {st }}$ order polynomial filter, which shows that the gradient is generally increasing towards the NNE and decreasing towards the SSW. While; Fig. 9 was obtained through the $2^{\text {nd }}$ order polynomial filter and illustrates more resolved regional geothermal gradient with general geothermal gradient increase towards the northeast, at localized regions within the southeastern and northwestern rims of the study area. 
Helaly, A. S.

\section{Geothermal Gradient versus Depth}

The Geothermal Gradient is simply the rate of increase in temperature per unit depth in the Earth. Although the geothermal gradient varies from place to place, it averages 25 to $30^{\circ} \mathrm{C} / \mathrm{km}$. Temperature gradients sometimes increase dramatically around volcanic areas. It is particularly important for drilling fluids engineers to know the geothermal gradient in an area when they are designing a deep well. The downhole temperature can be calculated by adding the surface temperature to the product of the depth and the geothermal gradient.The relationship between geothermal temperature and depth is the key point to evaluate the geothermal potential in any area.

Fig. 8: Regional geothermal gradient ( $1^{\text {st }}$ order)

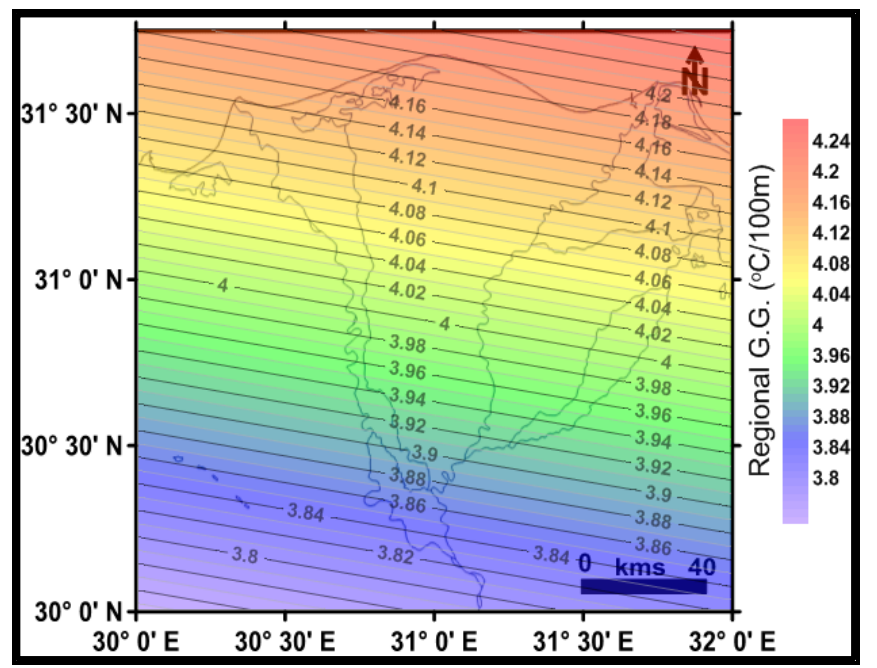

Changwei (2016) divided geothermal temperature-depth graph into five applicable parts; geothermal direct use area, moderate temperature hydrothermal reservoirs area (pumped wells), high temperature hydrothermal reservoirs area (self-discharging wells), stratigraphic geothermal reservoirs (SGR) area, traditional petroleumreservoir (TPR) area and high pressure and high temperature (HPHT) petroleum reservoir area. It is noted that geothermal resources from moderate temperature hydrothermal reservoirs, high temperature hydrothermal reservoirs, and stratigraphic geothermal reservoirsare in good favor of power generation. This is illustrated in Figure 10, where the obtained maximum temperatures range (less than $150{ }^{\circ} \mathrm{C}$ within the 4000 meters average depth).

It can be concluded that the subsurface geothermal resources within the Nile Delta can be mainly in the form of the first two categories [geothermal direct use area and moderate temperature hydrothermal reservoirs area (pumped wells)] with some moderate temperature petroleum reservoirs.

The temperature-depth curves are usually showing consistent increase in temperature with depth. While, the geothermal gradient-depth curves are commonly showing increases and decreases with depth because of the much effects on wells from the lithological composition and its contents (Fig. 11).

In the current study, the variation of the geothermal gradient with depth has been estimated at discrete depth intervals to get as much informative detailed knowledge about its variation with depth and its meaning from the geological point of view about the characteristics of the penetrated rock formations, which is the main goal of the this study. That is to conclude the nature of the penetrated rock formations, whether of sandy or shaly (clayey) composition. This main composition will be reflected of the analyzed geothermal gradient with depth. The penetrated wells are of different total depth values; therefore, it was not possible to determine or investigate all the formations penetrated by some wells for its whole sequence. The detailed vertical geothermal gradient was estimated in each well.

Measuring the temperature in a well is useful for determining the Earth's subsurface gradient at that location. Reviewing the gradient (change in temperature over the change in depth) gives clues as to what is happening underground. When comparing multiple wells in a close proximity, the subtle constituents and the heat transfer are noticeable (Thomas and William, 1982). 
Certain patterns are identifiable once there is an understanding of how temperature reacts to different mediums and situations. The following simple figure shows an example of how temperature-depth \& geothermal gradient-depth curves can differ and what these differences mean in terms of subsurface lithological zonation.

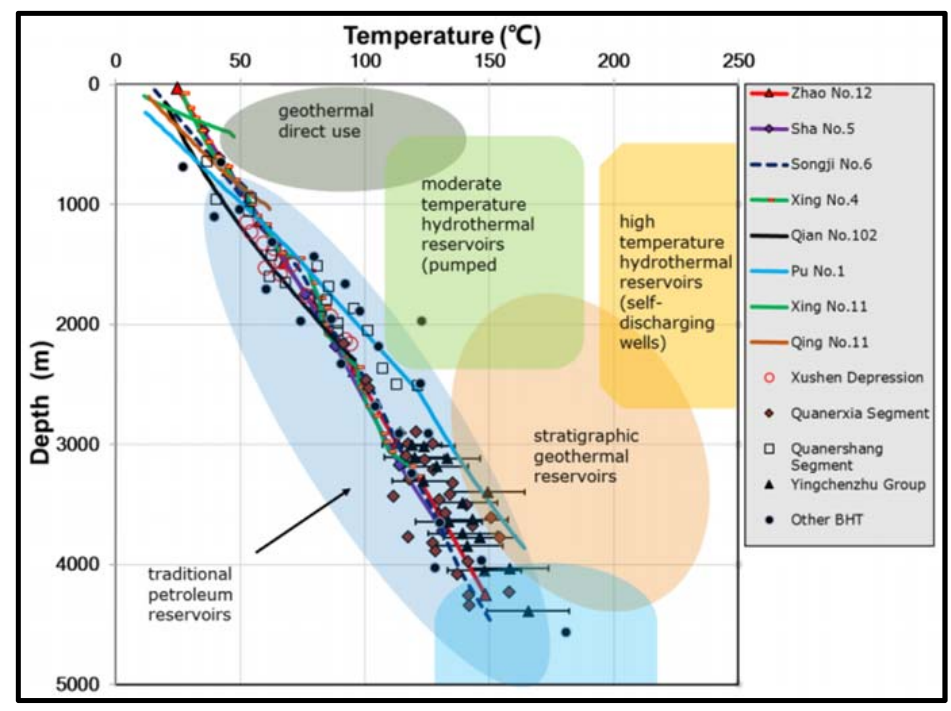

Fig. 10: Geothermal temperature versus depth based on data from DQ oilfields (Changwei (2016).
Fig. 11: T-D and GG-D in relation with different subsurface lithological composition (Thomas and William, 1982).

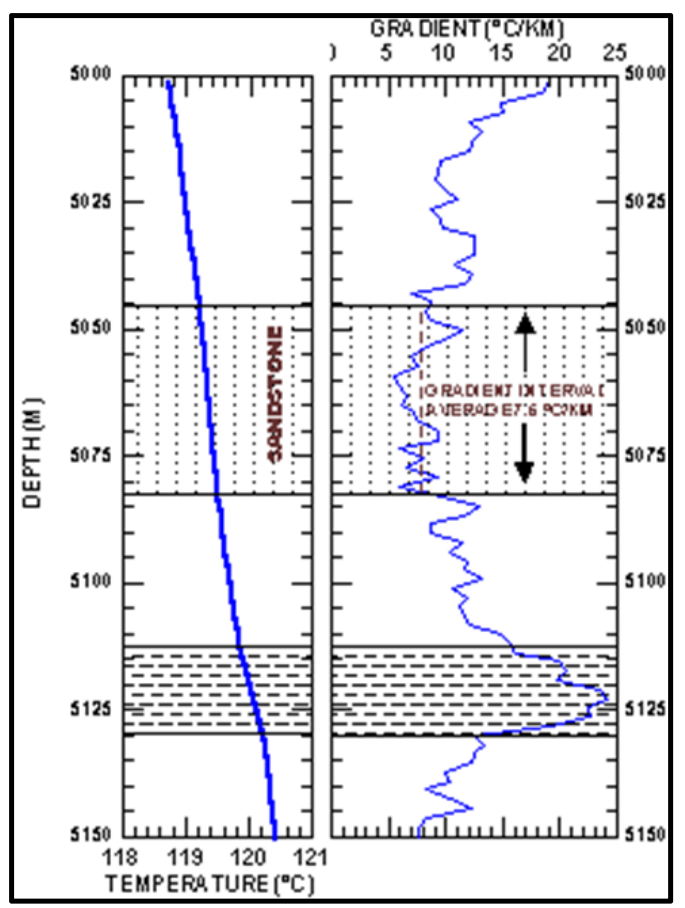

\section{Geothermal Gradient-Lithological Zonation in the study area}

An attempt has been carried to interpret the vertical variation in geothermal gradient in terms of lithological constituents within each of the studied wells throughout the study area. Due to the incompleteness of temperature data from some wells and due to the different wells' total depths in the studied wells, some depth values for some lithologic formation were inferred from the geographical relation between the wells. Before proceeding in the use of the geothermal gradient in the zonation of the subsurface geologic sequences, it is worth to shed some light about how the knowledge of thermal properties of the materials that constitute the earth's interior help to understand the thermal structure in the subsurface. 
Helaly, A. S.

Sedimentary rocks are characterized by a broad scatter of thermal properties within a single lithological type. This is originated mainly by the complex influence of mineral composition, texture and grain cementation, porosity, and pore fluids.In porous sedimentary rocks, porosity and moisture content gives a dominant effect on the thermal conductivity of rocks. Thermal behavior is strongly influenced by the distinct difference of thermal properties between the solid matrix material (minerals) and the various porefilling materials.

The rocks' thermal conductivity is of crucial importance in geothermal studies. It is related to the amount of heat flow from any area through the geothermal gradient component. In case of thermal conduction, the geothermal gradient is inversely proportional to the thermal conductivity for rock unit or geologic sequence in general. Therefore, subsurface horizons that show high geothermal gradient are usually having lower thermal conductivity rock constituents. Among the rock texture elements that influence the thermal conductivity is the grain size. Where, the finer grains usually cause a decrease in thermal conductivity than the coarser mineral grains due to the increase of the number of grain contacts per the rock's unit volume. Also, the cementation controls, strongly, the rock's thermal conductivity because the dominant thermal conductor is the rock skeleton.

Among the main rock-forming minerals, Quartz (constituting the sandstone rock formations) has high thermal conductivity, while clay minerals (constituting clayey and/or shaly rock formations) have lower thermal conductivity values.

Also, the contained fluids with the pore system in these rocks are also contributing to the rock formations' thermal conductivity, where water has higher thermal conductivity than oil than gas.

The thermal properties of the rock formations show higher range of variation in thermal conductivity than their constituting minerals that reflect smaller range of variation in their thermal properties. This wider range of variation is due to the heterogeneity in rock composition, in addition to the diversity in mineral content, rock texture, and fluid content. Therefore, a higher thermal conductivity for watersaturated rocks and a lower conductivity for gas-bearing or dry porous rocks can be expected.In general, increasing rock porosity and fracturing leads to a decrease in the thermal conductivity of the rock, and a consequent increase in the geothermal gradient of the rock formation.

Therefore, in summary, there are many factors that affect the thermal conductivity of rocks, and this will be reflected on the resultant geothermal gradient. Therefore, the geothermal gradient variation, either horizontally or vertically, has a great role in understanding the nature of the constituents of rock formations. This perception was used in deciphering the rock formations penetrated by the drilled wells.

In the current study area, the Post-Miocene sequence is primarily composed of the rock formations mentioned earlier in this paper work (summary is given in Table (4) in the form of almost alternating shaly and sandy rock formations. An attempt of interpreting such geothermal gradient variation in terms of lithological variations has been carried out to infer the vertical sequence in rock formations in each well, from the thermal point of view.

To validate (at least) some of the studied lithologies, the author referenced some of the results with some references for the available wells in the Nile Delta. For example, (Ezz El-Din, et al. 2013; Mansoura Pet. Co., 2007 and Hafez and Castagna, 2016) through their study of the petrophysical parameters using well logs in Nile Delta, pointed out from the neutron/Gamma-ray cross-plots, that medium Gamma- ray (40-55 API) and medium neutron porosity indicate shaley sandstone, while high Gamma-ray (greater than 55 API) and high neutron porosity suggest rich shale.

And, such low to medium gamma ray measurements were in good correlation with the zones of low geothermal gradient values indicating sandy formations like Abu Madi and Qawasim formations in the Nile Delta. By comparison (in their work), they found the Neutron/Gamma-ray cross plotsand the Neutron/Density cross plots are consistent, showing the main lithology of the Abu Madi (an example for the Sandy formations) Unit is sandstone with occasional shale intercalations, which is expressed as a zone of low geothermal gradient in this work.In general, for referencing the estimated geothermal gradient in the current study, it is found that the sandy-dominated depth intervals were within the geothermal gradient 
range of about $2( \pm)^{\circ} \mathrm{C} / 100 \mathrm{~m}$, while the shaley/clayey-dominated depth intervals were in the geothermal gradient range of about $4( \pm)^{\circ} \mathrm{C} / 100 \mathrm{~m}$. The resulted geothermal gradient values throughout the depth range of all studied wells were fed into an Excel sheet and graphed, as shown in Fig. 12. For simplifying the results' graphing, an example of the accomplished work was illustrated by the results of Well\#1 and Well\#2 as illustrated in Fig. 12.
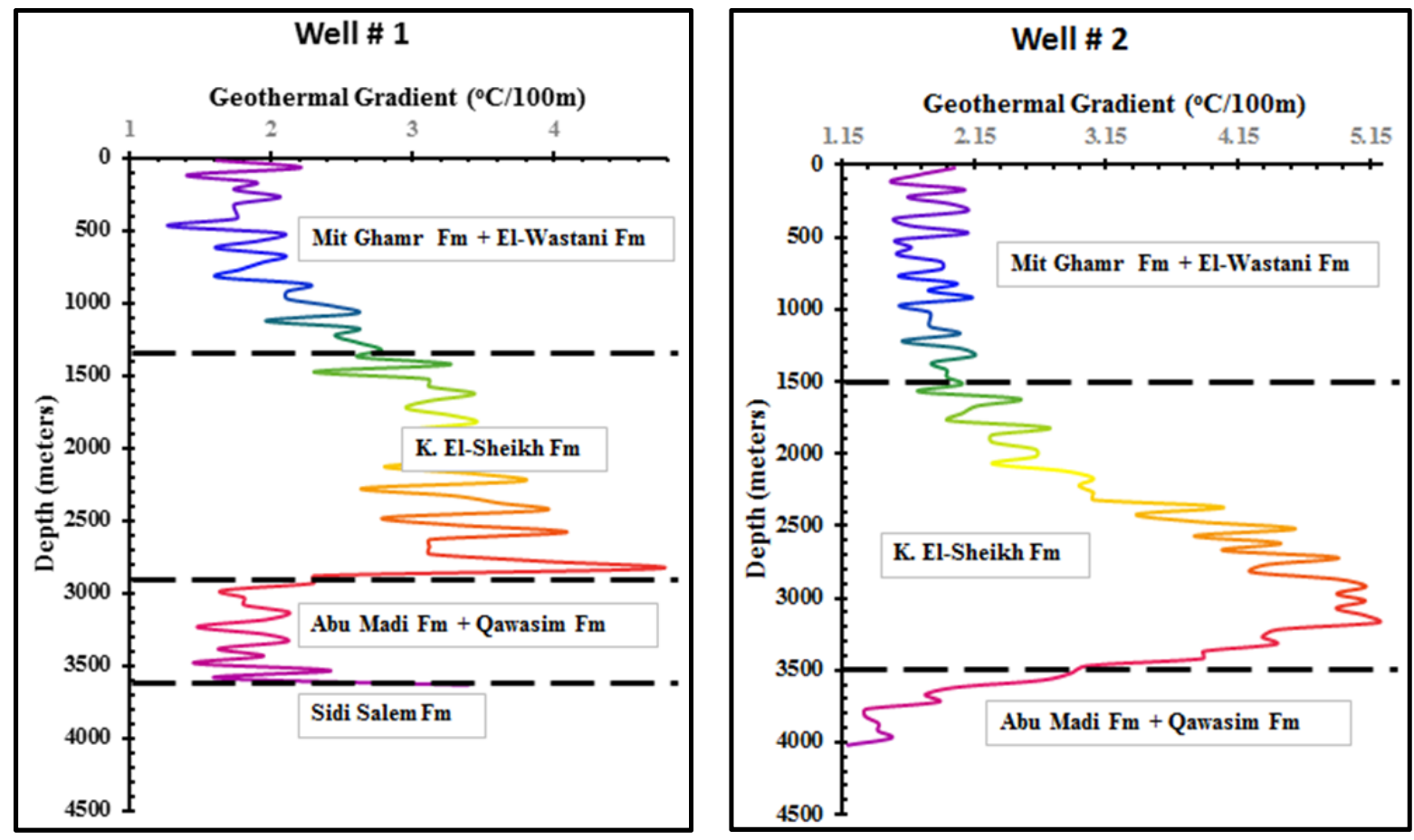

Fig.12: Well\#1 and Well\#2 geothermal-lithological zonation.

Since it is neither straightforward nor possible to distinguish between the different sandy lithologies composing the Bilqas, MitGhamr, and El-Wastani formations from just geothermal gradient graphs, in this work, those three formations were compiled together as one unit termed (Unit I). Kafr El-Sheikh Formation with its Clayey/Shaley main composition was considered as another unit termed (Unit II). The underlying Abu Madi and Qawasim sandy Formations were termed (Unit III). And finally, Sidi Salem (shaley/clayey) Formation is represented as (Unit IV). Rosetta Formation with its hydrochemicalevaporitic composition (if exists) is termed (Unit V). Table (4) summarizes the mentioned information.

Table 4: Summary of the depth and lithologic information for the subsurface formations

\begin{tabular}{|c|l|l|c|c|l|}
\hline \multirow{2}{*}{ Unit } & \multicolumn{1}{|c|}{ Fm } & $\begin{array}{c}\text { Type Section } \\
\text { in Well..... }\end{array}$ & $\begin{array}{c}\text { Depth Range } \\
\text { (m) }\end{array}$ & $\begin{array}{c}\text { Thickness } \\
\text { (m) }\end{array}$ & \multicolumn{1}{|c|}{ Main Lithology } \\
\hline \multirow{2}{*}{ I } & Bilqas & Bilqas\#1 & 0 to 25 & 25 & Sand interbedded with clay \\
\cline { 2 - 6 } & MitGhamr & Mit Ghamr\#1 & 20 to 483 & 463 & Sand and pebbles \\
\cline { 2 - 6 } & El Wastani & El Wastani\#1 & 1009 to 1132 & 123 & $\begin{array}{l}\text { Quartzose sandstone interbedded with } \\
\text { clay }\end{array}$ \\
\hline II & Kafr El Sheikh & Kafr E1 Sheikh\#1 & 1277 to 2735 & 1458 & Clay interbedded with sands \\
\hline \multirow{2}{*}{ III } & Abu Madi & Abu Madi\#1 & 3007 to 3329 & 322 & $\begin{array}{l}\text { Cross-bedded Sand interbedded with } \\
\text { clay }\end{array}$ \\
\cline { 2 - 6 } & Qawasim & Qawasim\#1 & 2800 to 3733 & 933 & Sands, sandstones \\
\hline IV & SidiSalim & Sidi Salim\#1 & 3592 to 4038 & 446 & Clay \\
\hline
\end{tabular}

\section{DISCUSSION}

The studied wells are separated by different distances as shown in Figure 1. The studied thermal data were from the surface to varying depths between about 2000meters (at Hosh Isa Well) and about 4400 meters (at SW-Bilqas and Ras El-Bar Wells), (Table 2). 
Helaly, A. S.

From the geothermal point of view, if some deeper formations represent some sort of heat reservoirs (e.g. Abu Madi and Qawasim Formations), they are trapped by barrier lithologies (of lower thermal conductivity) e.g. the Clays of Kafr El-Sheikh (above) and Shales\& Clays of SidiSalim (below).

The temperature gradient logs from the studied wells (Fig. 13) shows some sort of correlation between the majorities of wells except the wells of some missing formations, and also, the thermal gradient profiles are showing some non-correlation with depth due to the lithological heterogeneities within the different studied formations. The large oscillations and some of the differences between the different logs of some wells (especially that reflect the sandy Abu Madi Formation) reflect the probability that these holes are in an older andproductive hydrocarbon field.

Another reason for the gradient variations may represent or reflectvarying production disturbances in the formations caused by moving fluids andexpanding gas, or, some sort of lithological compositional heterogeneity. The lithologies penetrated by the studied wells are dominantly sand and shale. The highergradient sections correspond to zones that are higher in shale content, whereas lower gradientsoccur in sand-rich sections.

The lowest gradients in these wells are about $0.12^{\circ} \mathrm{C} / 100 \mathrm{~m}$ in Well \#20 and occur in varying intervals of the wells indicating clean sandy formations.Gradient highs show more variation with a range up to $9^{\circ} \mathrm{C} / 100 \mathrm{~m}$, tending to increase with depth down in some shaley (e.g. Kafr El-Shaikh) formations.

In some wells (e.g. Well\#5, 8, 9, 10, 14, 15, 16, 20 \& 24), the unit \#1 (U1) shows unusual higher gradient up to less than $3{ }^{\circ} \mathrm{C} / 100 \mathrm{~m}$, reflecting the effect of relative unusual increase of the clayey interbeds within the upper sandy formations (Figure 14). In Well\#14 (for example), MitGhamr Fm with its sandy composition is expected to be of low geothermal gradient. But, may be its clayey content was much enough to decrease its thermal conductivity and increasing (locally) its geothermal gradient. This trend is more towards the western side of the Nile Delta. And also, some units of mainly shaley or clayey compositional nature exhibit unexpected lower gradient due to the relative increase of the sandy content within such formations.Unit\#2 (Kafr El-ShaikhFm) most likely are showing narrower range of local gradient variation, that reveal the more homogeneity in its shaley or clayey composition than in other locations.

Due to the significance of Abu Madi Formation from the hydrocarbon-production point of view, an attempt was given to reveal some of its deduced topographic status below the ground surface. Figs. 15, 16, and 17 represent illustrations of the product from this work, in the form of three maps illustrating the depth to Top Abu Madi Formation (Fig. 15), the top of the Sidi Salim Formation (Fig. 16), and the thickness of the Abu Madi and Qawasim Formations (Fig. 17).

Fig. 15 shows the shallowest depth to Abu MadiFm is towards the south of the Nile Delta (around 1200 meters below ground surface) and increasing northward in local basin-like depression down to around 2700 meters below ground surface).

The depth to the top of SidiSalim clayey formation (Fig. 16) is also less towards the southern rim of the Nile Delta, where it is at a depth of about 1900 meters below the ground surface. Also, its depth is increasing northward, with slight contour perturbations, to a depth of about 3900 meters at the center and to the north of the Nile Delta.

From the two maps (Figs. 15 and 16), another isopach (thickness variation) map (Fig. 17) was deduced for Unit III (Abu Madi and Qawasim Formations).This sandy unit shows its maximum thickness within the middle of Nile Delta, slightly to the north of Well\#11, with another north-southstrip-like increase at the eastern side of the study area. The minimum thickness of this unit is encountered to the southern and western sides of the Nile Delta.

Two diagrammatic subsurface sections were constructed to illustrate the relative subsurface relief of the interpreted units along the two directions, W-E (Fig. 18) and S-N (Fig. 19). 
Use of the geothermal gradient variations in zoning of Post- Miocene Sequence

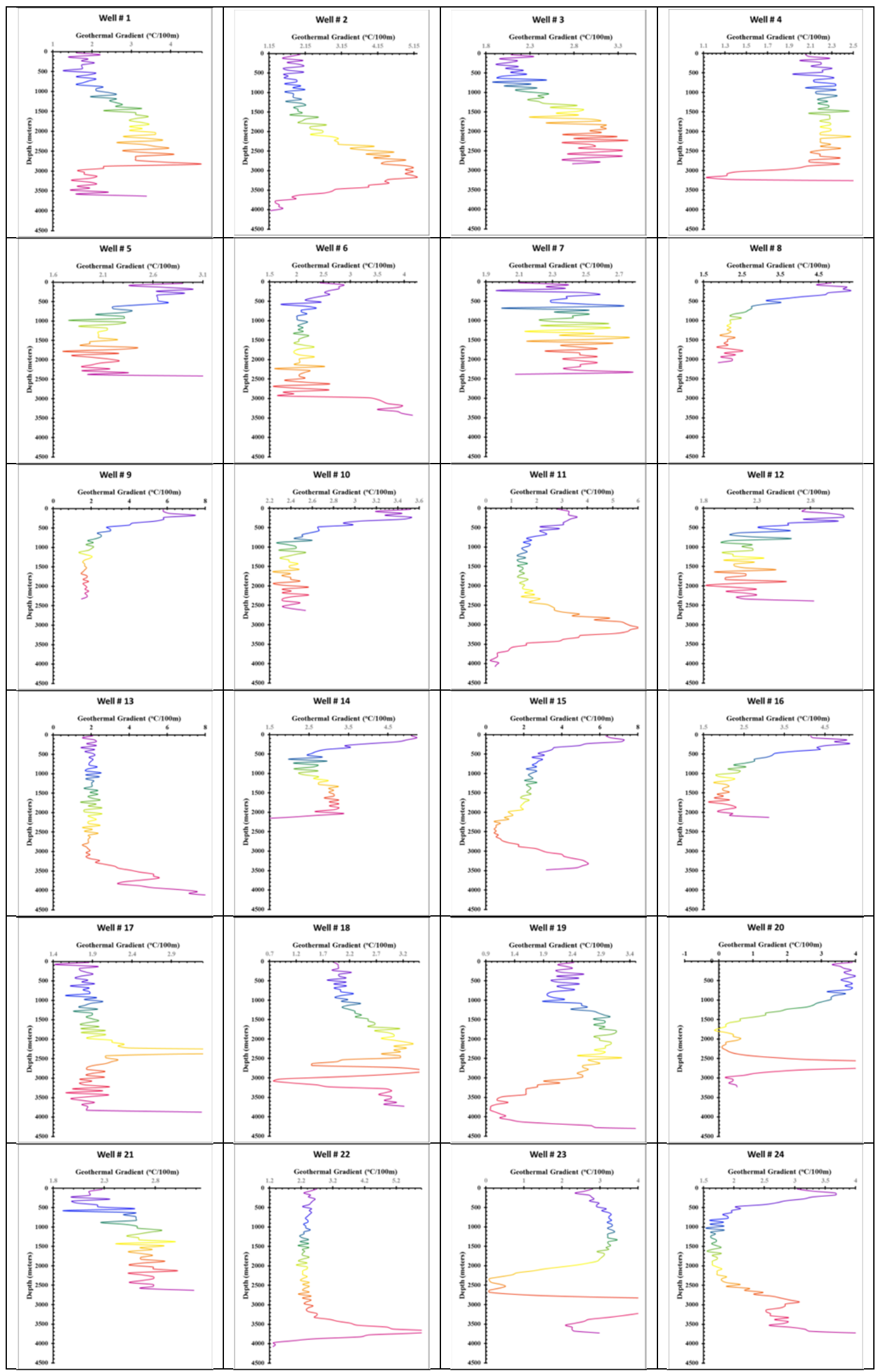

Fig. 13: The vertical variation of geothermal gradient with depth for the studied wells. 
Helaly, A. S.

Fig. 14: Wells showing the increase in shale content in Unit I
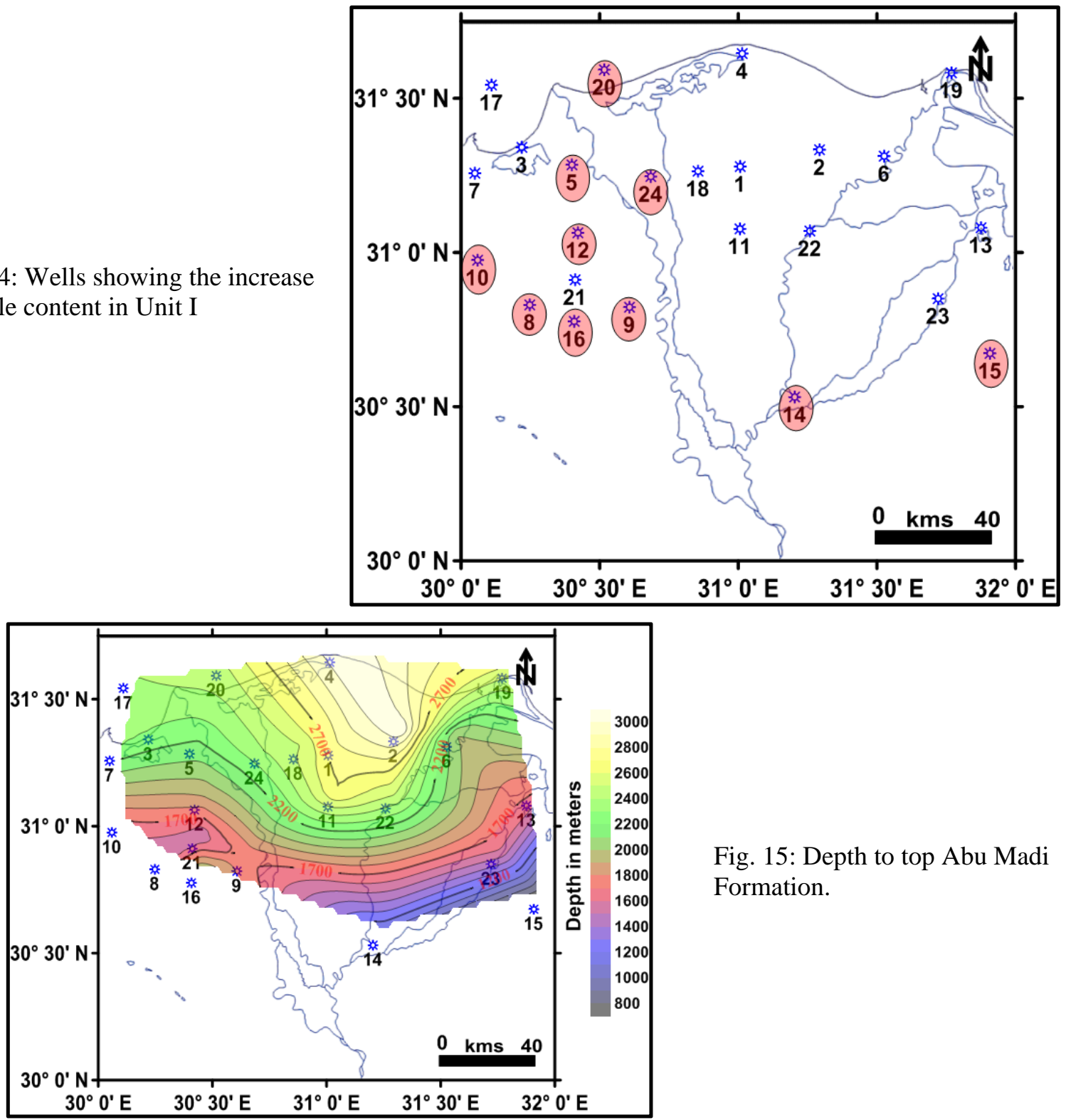

Fig. 15: Depth to top Abu Madi Formation.

Fig. 16: Depth to top Sedi Salim Formation.

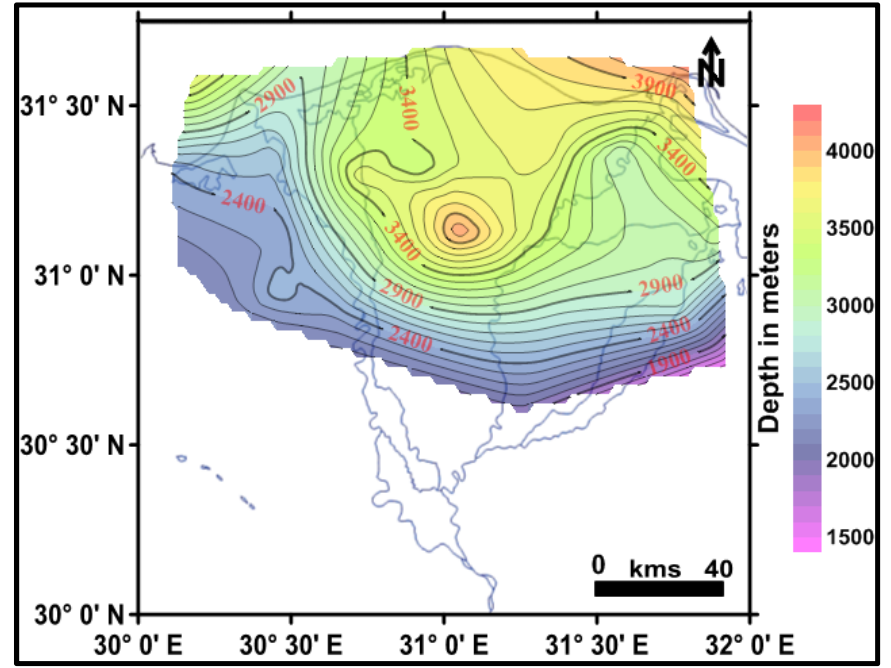




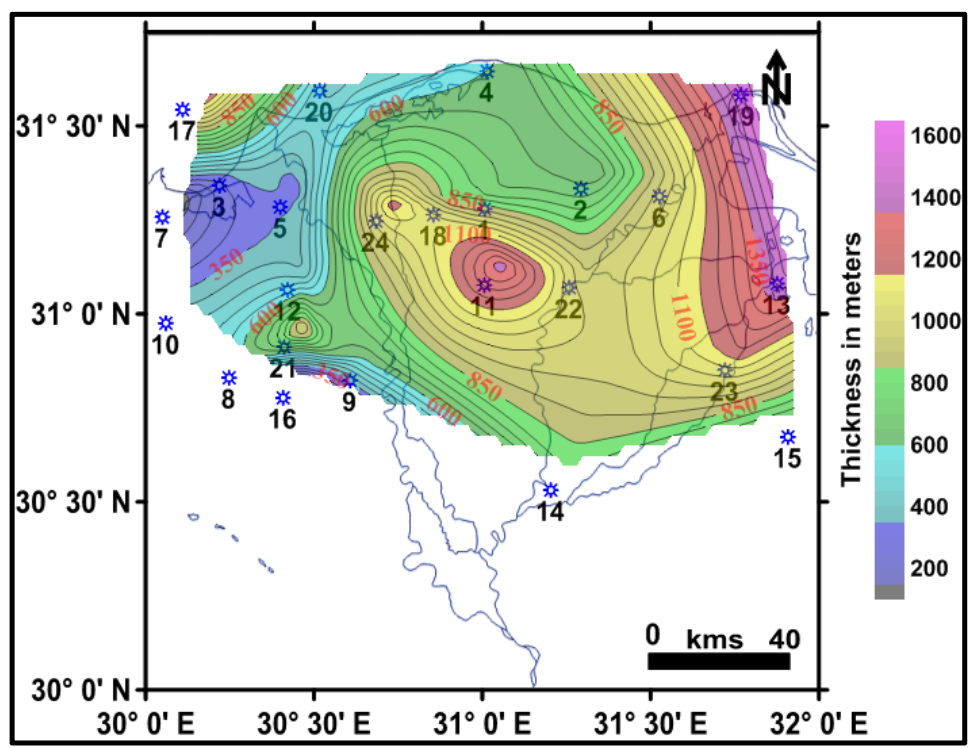

Fig. 17: Thickness map for U3(Abu Madi and QawasimFm) C.I. $=50$ meters.

Fig. 18: Interpreted diagrammatic subsurface geologic X-section E-W (through the marked wells).
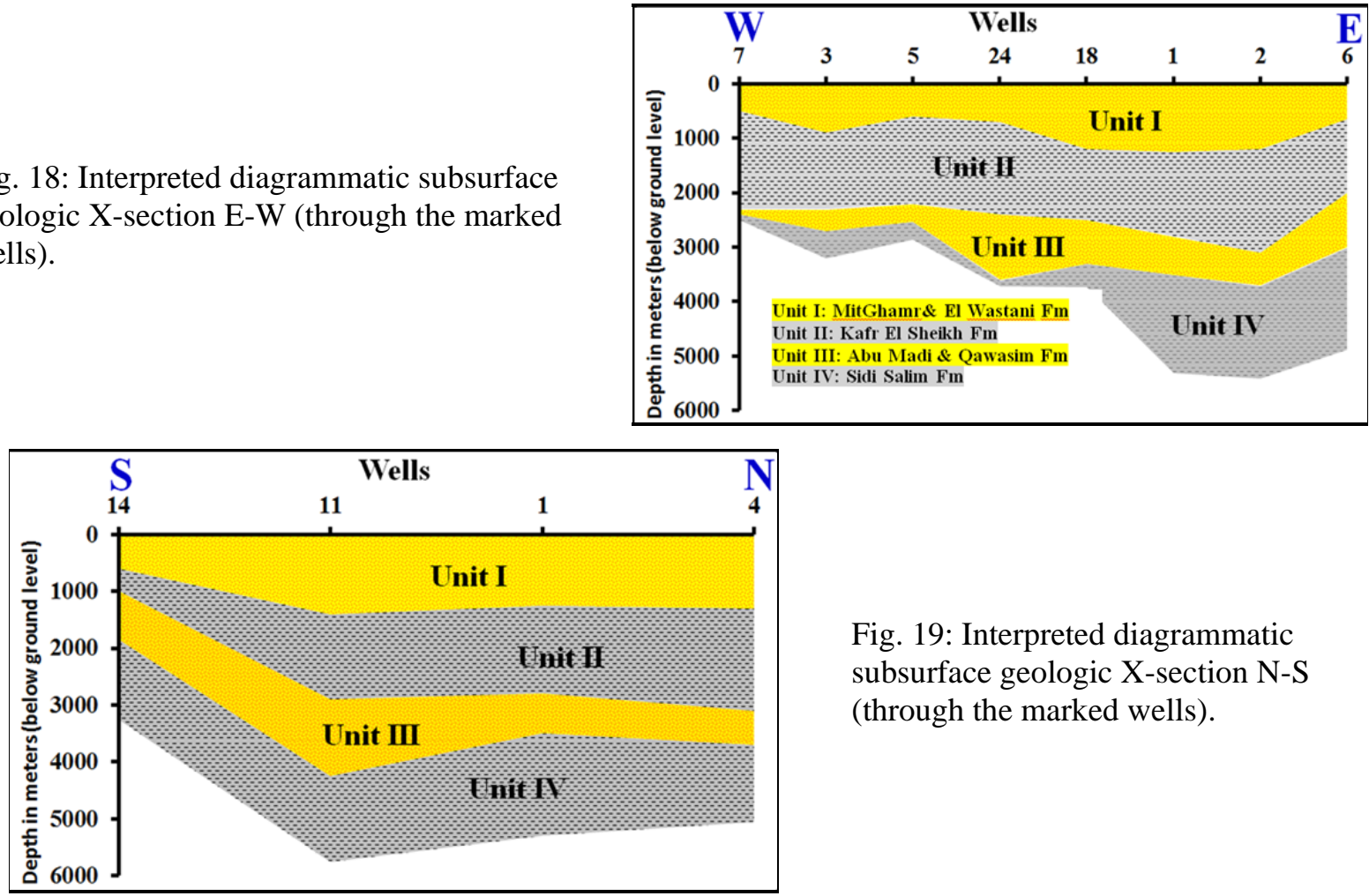

Fig. 19: Interpreted diagrammatic subsurface geologic $\mathrm{X}$-section $\mathrm{N}-\mathrm{S}$ (through the marked wells).

Geothermal gradient analysis has been carried out for twenty four well data sets in the form of depthtemperature information. The temperature data were measured at different not equal/regular depths within each well. The depth- temperature data in each well were individually profiled and re-digitized at regular depth intervals to be prepared for the subsequent analysis. The regularly-spaced temperature data were then corrected for the eliminating the effect of mud circulation during drilling. Six methods were used for the temperature corrections, Harrison Correction, Original Förster Correction, Modified Förster correction (SMU Geothermal Laboratory), Forster/Merriam/Davis Correction, General average AAPG Correction and, Andrews-Speed Correction. 
Helaly, A. S.

The last two correction schemes were chosen, for the subsequent interpretation, which gave the closest integration with the observed temperature data. The new corrected Depth-Temperature data sets for all wells were used to estimate the general geothermal gradient for the intended subsurface Miocene and postMiocene rock formations within the entire area. Four alternating high and low general geothermal gradient were deduced, with a range of 3.48 to $4.69 \mathrm{oC} / 100 \mathrm{~m}$. Then to get an idea about the trend of geothermal gradient increase, the regional geothermal gradient was estimated through the first and second polynomial surfaces. It showed a general increase towards the north north-east with some localization at the eastern and northern directions. Then, the local geothermal gradient was estimated within each well.

The calculated geothermal gradient was plotted against depth and analysed for the different subsurface rocky formations. The depth intervals with higher local geothermal gradient were reflecting the existence of lower conductive lithologies (e.g. Shale of Clay composition), whereas, the depth intervals with lower local geothermal gradient were reflecting the existence of higher conductive lithologies (e.g. Sandy composition). These results were correlated with some gamma-ray logs for the subsurface rock formations within the Nile Delta. Close approximated results were obtained, which indicated that the use of DepthTemperature data can be helpful in identifying the subsurface lithologies.Due to the difficulty of discriminating the different sandy lithologic formations based only on the thermal characteristics, the upper three sandy formations were considered as one unit termed Unit\#1. Kafr El-Shaikh Fm with its much thickness was assigned as Unit\#2. Then, the underlying sandy Abu Madi and Qawasim Formations were compiled in one unit named Unit\#3. Then, the lowermost Clayey Sidi Salim Formation was given Unit\#4.

The current study involved a trial for following the four units in the subsurface based on their thermal characteristics. Two maps were drawn for the top Abu Madi and top Sidi Salim formations, for producing another illustration for the thickness variation with the Uni\#3 (AbuMadi and Qawasim) formations for its importance as the main hydrocarbon storing formation within the study area. Then, two diagrammatic cross-sections were sketched in the E-W and N-S directions to follow the subsurface relative relief of the subsurface units.

\section{REFERENCES}

Abd El Aal, A., Day, R. A. and Lelek, J. J., (1992): Structural evolution and styles of the Northern Sinai, Egypt, EGPC., $7^{\text {th }}$ Expl. and Prod. Conf., Cairo, 546-562.

Abdel Aal, A., Price, R. J, Vaitl, J. D. and Shrallow, J. A., (1994): Tectonic evolution of the Nile Delta, its impact on sedimentation and hydrocarbon potential, EGPC., Proc. $12^{\text {th }}$ Pet. Conf., Cairo, 12(I), 19-34.

Abel Halim, A., (2001): Future hydrocarbon potential in the Nile Delta offshore and onshore, $1^{\text {st }}$ Inter. Sympo. on the Deltas, , Modern and Ancient, Cairo, Egypt. 159-174.

Abu El Ella, R., (1990): Maturation history of Neogene-Quaternary sediments, Nile Delta basin, Egypt, AAPG, 74(1), 1990, 77-84.

Hafez, A. and Castagna,, J. P.,(2016): Distinguishing gas-bearing sandstone reservoirs within mixed siliciclastic-carbonate sequences using extended elastic impedance: Nile Delta-Egypt, Interpretation 4 (4): T427-T441.

Allis, R.G., Gwynn, M., Hardwick, C. Kirby, S. Moore,J.and Chapman, D., (2015): Re-evaluation of the Pre-Development Thermal Regime of Roosevelt Hot Springs Geothermal System, Utah, Proceedings, $40^{\text {th }}$ Workshop on Geothermal Reservoir Engineering, Stanford University, CA.

American Association of Petroleum Geologists (AAPG), (1976): Basic data file from AAPG geothermal survey of North America, University of Oklahoma, Norman, Oklahoma.

Andrews-Speed C. P., Oxburgh E. R., and Cooper B. A., (1984): Temperatures and Depth-Dependent Heat Flow in Western North Sea. The American Associalion of Petroleum Geologists, V. 68, No. 11 (November 1984), P. 1764-1781, 15 Figs., 2 Tables

Arisi Rota F., Palmieri G., Quagliaroli F., (1994): Nile Delta Basin-Geological and structural setting, (IEOC internal report). 
Use of the geothermal gradient variations in zoning of Post- Miocene Sequence

Blackwell, D. D., and Richards, M., (2004): Calibration of the AAPG Geothermal Survey of North America BHT Data Base, American Association of Petroleum Geologists Annual Meeting 2004, Dallas, Texas, Poster session, paper 87616.

Blackwell, D. D., Richards, M., and Stepp, P., (2010): Texas Geothermal Assessment for the I-35 Corridor East, Texas State Energy Conservation Office Contract, pp. 88.

Changwei, L., Li, K., Chen, Y. and Chen, J., (2016): Geothermal Gradient in The Oilfields In China. Proceedings $41^{\text {st }}$ Workshop on Geothermal Reservoir Engineering Stanford University, Stanford, California, February 22-24, 2016 SGP-TR-209.

Crowell, A. M., and Gosnold, W. D., (2011): Correcting Bottom-Hole Temperatures: A Look at the Permian Basin (Texas), Anadarko and Arkoma Basins (Oklahoma), and Williston Basin (North Dakota), Geothermal Resources Council Transactions, 35, 735-738.

Deibis, S., Futyan, A. R. I., Ince, D. M., Morley, R. J., Seymour, W. P. and Thompson, S., (1986): The stratigraphic framework of the Nile Delta and its implications with respect to the regions hydrocarbon potential, EGPC, Expl. \& Prod. Conf., Cairo, 2(2), 1986, 164-175.

EGPC (Egyptian General Petroleum Corporation), (1994): Nile Delta and north Sinai Fields, discoveries and hydrocarbon potential (a comprehensive overview). The Egyptian Petroleum Corporation, Cairo, Egypt, 1994, 387 p.

Egyptian General Petroleum Corporation, (1994): Nile Delta and north Sinai Fields, discoveries and hydrocarbon potential (a comprehensive overview), The Egyptian Petroleum Corporation, Cairo, Egypt, 387p.

El Alfy, M., Polo, F. and Shash, M., (1992): The geology of Abu Madi Gas Field, EGPC, $11^{\text {th }}$ Pet. Expl. and Prod. Conf., Cairo, 2, 1992, 485-513.

El Heiny, I. and Enani, N., (1996): Regional stratigraphic interpretation pattern of Neogene sediments, northern Nile Delta, Egypt, $13^{\text {th }}$ EGPC. Expl. Petr. Conf., Cairo, 1, 1996, 270-290.

Elbosraty, M., (2005): Sequence stratigraphy of the Nile Delta with emphasis on the basin analysis, unpublished Ph. D. Thesis, Ain Shams Univ., Egypt, 2005, 282 p.

Ezz S El-Din, Maher A Mesbah, Mohamed A Kassab, Ibtehal F Mohamed, Burns A Cheadle, Mostafa A Teama., (2103): Assessment of petrophysical parameters of clastics using well logs: The Upper Miocene in El-Wastani gas field, onshore Nile Delta, Egypt. Petrol. Explor. Develop., 2013, 40(4): 488-494.

Förster, A., Merriam, D. F., and Davis, J. C., (1996): Statistical analysis of some bottom-hole temperature (BHT) correction factors for the Cherokee Basin, southeastern Kansas: Tulsa Geol. Soc. Trans., 3-9.

Forster, A., and Merriam, D. F. (1995).Geothermal field interpretation in south-central Kansas for parts of the Nemaha Anticline and flanking Cherokee and Sedgwick Basins. Basin Res., 5(4), 213-234

Harrison W. E., Luza, K.V., Prater, M. L., and Chueng, P. K., (1983): Geothermal resource assessment of Oklahoma, Oklahoma Geological Survey, Special Publication 1-83.

Hemdan, K., El Alfy, M., Enani, N., Barrasi, M., and Monir, M., (2002): Structural Complexity of Pliocene and its Impact on Trapping Mechanism, N. Port Said Concession, Egypt. Mediterranean offshore conf..

Ismail, A., Boukhary. M and Abdel Naby A. I., (2010): Subsurface Stratigraphy and micropaleontology of the Neogene rocks, Nile Delta, Egypt, Geologia Croatica, 63(1), 2010, 1-26.

Kehle, R.O., (1972): Geothermal survey of North America, Am. Assoc. Petroleum Geologists, 1971 Annual Progress Report, 31p.

Kehle, R.O., (1973): Geothermal survey of North America, Am. Assoc. Petroleum Geologists, 1972 Annual Progress Report, 28p.

Khaled, K. A., Attia G. M., Metwalli F. I. and Fagelnour M. S.(2014): Subsurface Geology and Petroleum System in the Eastern Offshore Area, Nile Delta, Egypt, Jour. of applied sci. research, 10(4), 254-270.

Kora, M., (1980): Geology of Tertiary-Quaternary subsurface sedimentary succession, West Nile Delta area, unpublished M. Sc. thesis, Mansoura Univ., Egypt, 254p.

Mansoura Pet. Co., (2007): Seismic sequence stratigraphy and facies architecture of Miocene reservoirs of West Al Khilala Field, (Internal report, Mansoura Petroleum Company), 2007, 106 p. 
Helaly, A. S.

Mosconi, A., Rebora, A., Venturino, G., Bocc, P., and Khalil, M. H., (1996): Egypt - Nile Delta and North Sinai Cenozoic tectonic evolutionary model. EGPC, 13th Petrol. Exp. Prod. Conf., Cairo, 2, 203-223.

Nashaat, M., Abnormally high fluid pressure and seal impacts on hydrocarbon accumulations in the Nile Delta and North Sinai Basins (1998): In: Abnormal Pressures in Hydrocarbon Environments, (Law, B.E., Ulmishek, G. F. \&Slavin, V. I., 1998 edits), AAPG Bull., 70, 1998, 161-180.

Rizzini, A., Vezzani, F. and Milad, G., (1976): Stratigraphy and sedimentation of Neogene Quaternary section in the Nile Delta area, A. R. E., Marine Geol.,27, 327-348.

Sarhan, M. and Hemdan, K., (1994): North Nile Delta structural setting and trapping mechanism, Egypt, EGPC., Proc. of the 12th Pet. Conf., Cairo, 12, I, 1-17.

Schlumberger (1985): Log interpretation charts, Schlumberger,U.S.A., 1985, 111 p.

Shehata, A. M., (2008): Geological and petrophysical studies on Miocene oil reservoir of the deep target Sidi Salem sandstone, onshore Nile Delta, Egypt, MOC, Alex. Egypt, abstract, 2008.

Abd El Hafeez, T., El Kadi H. H. and El Geuoshi (2014): Quantitative Well-Log Analysis of Gas Reservoirs at South Batra Field, Nile Delta, Egypt. Austin J Earth Sci., 1(1): 7.

Thomas, C. and William H. D., (1982): An Interpretation of Precision Temperature Logs in a Deep Geothermal Well Near Desert Peak, Churchill County, Nevada, Geoth. Res. Council Transactions, 6, 317-320.

Zaghloul, Z. M., Elgamal, M. M., El Araby, H. and Abdel Wahab, W., (2001a): Evidences of geotectonic and ground motions in the Northern Nile Delta, In: Deltas modern and ancient (Zaghloul, Z. and Elgamal, M. M., 2001 edits.), Mansoura Univ., 285-314.

Zaghloul, Z. M., Elgamal, M. M., Shaaban, F. F. and Yossef, A. F., (2001b):. Plates interactions and petroleum potentials in the Nile Delta, In: Deltas modern and ancient (Zaghloul, Z. and Elgamal, M. M., 2001 edits.), Mansoura Univ., 41-53.

Zaghloul, Z. M., Shaaban, F. F. and Yossef, A. F., (2001): Mesozoic and Cenozoic sedimentary basins, Nile Delta, Egypt, In: Deltas modern and ancient (Zaghloul, Z. and Elgamal, M. M., 2001 edits.), Mansoura Univ., 2001c, 21-33. 
Use of the geothermal gradient variations in zoning of Post- Miocene Sequence

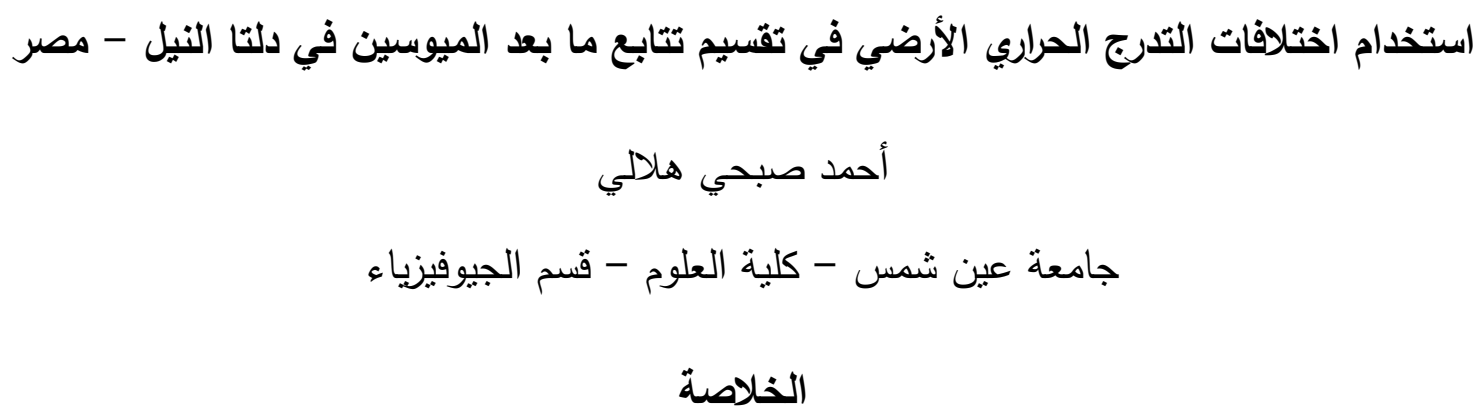

بعتبر التدرج الحراري الأرضي من بين أهم المدلولات الحرارية للصخور ومركباتها المعدنية. ويلعب التدرج الحراري الأرضي دورًا هاما في التعبير عن الظروف الحرارية تحت السطحية في أي منطقة. بعد إجراء التصحيحات اللازمة للبيانات الحرارية المتاحة ، تم استخدامها لتقدير وتوضيح إختلافات تدرج الطاقة الحرارية الأرضية مع العمق. - مع.

باستخدام هذه النتائج، ثم إجراء محاولة لإستخدام مثل هذه الإختلافات في التعرف على الإختلافات التكوينية الصخرية تحت سطح الأرض في منطقة الدراسة على أساس الخصائص الحرارية لمختلف الصخور التحت سطحية ـ تم تحديد أربع وحدات رئيسية تحت سطحية وتم رسم خرائطها في دلتا النيل. 